\title{
Large Adrenal Pseudocyst: A Case Report
}

\author{
Mohamed Amine Azami' ${ }^{1}$, Othman Lahbali' ${ }^{1}$ Iliass El Alami², El Amine Ratbi ${ }^{3}$, Fouad Zouidia1, \\ Najat Mahassini ${ }^{1}$
}

\begin{abstract}
${ }^{1}$ Department of Pathology, University Hospital Ibn Sina, Mohammed V University, Rabat, Morocco
${ }^{2}$ Department of Oncology, Mohamed V Military Hospital, Mohammed V University, Rabat, Morocco

${ }^{3}$ Department of Visceral Surgery, University Hospital Ibn Sina, Mohammed V University, Rabat, Morocco

Email: dr.azamiamine.aa@gmail.com, othmane.lahbali@gmail.com,dr.elalami.iliass@gmail.com,eratbi14@gmail.com, zouaidiapathology@gmail.com, N.Mahassini@gmail.com
\end{abstract}

How to cite this paper: Azami, M.A., Lahbali, O., Alami, I.E., Ratbi, E.A., Zouidia, F. and Mahassini, N. (2017) Large Adrenal Pseudocyst: A Case Report. Surgical Science, 8, 197-202.

https://doi.org/10.4236/ss.2017.85023

Received: January 1, 2017

Accepted: May 2, 2017

Published: May 5, 2017

Copyright (c) 2017 by authors and Scientific Research Publishing Inc. This work is licensed under the Creative Commons Attribution International License (CC BY 4.0).

http://creativecommons.org/licenses/by/4.0/

\begin{abstract}
Introduction: Cysts of the adrenal gland are rare and are usually discovered incidentally, typically presented with abdominal pain or palpable mass. There are four categories of adrenal gland cyst: epithelial, endothelial, parasitic and pseudocysts. We report the case of a 33-year-old woman who presented as a pain of the right hypochondrium and abdominal distention and was diagnosed with a large unilateral adrenal pseudocyst. Case presentation: A 33year-old Moroccan woman followed for acute articular rheumatism for 3 years was admitted with left hypochondralgia and abdominal distention. Magnetic resonance imaging. (MRI) and abdominal computed tomography revealed a large left adrenal cyst mass measuring $19 \mathrm{~cm}$. The patient underwent surgery, and the cyst was completely removed. Histological examination revealed an adrenal pseudocyst. Symptoms resolved after pseudocyst removal. Conclusion: Adrenal pseudocysts are uncommon. Symptoms are usually related to the size and local pressure effect of the cysts.
\end{abstract}

\section{Keywords}

Adrenal Gland, Cyst, Pseudocyst, Surgery

\section{Introduction}

Adrenal pseudocysts are rare benign lesions. Mostly, these are small lesions discovered incidentally by imaging. The giant forms are rare. There are four categories of adrenal gland cyst: epithelial, endothelial, and parasitic and pseudocysts [1]. Clinical and radiological signs are not specific. Only pathological study can confirm the diagnosis and exclude malignancy. The treatment is based on surgery for large or symptomatic cysts. Through a new observation, we describe the different epidemiological, clinical, pathological features and treatment of this rare entity. 


\section{Case Report}

A 33-year-old woman followed for acute articular rheumatism for 3 years, presented with a 2-month history of nonspecific left hypochondralgia and abdominal distention. On examination, she was found to have a mass in the upper right quadrant that was dull to percussion and tender to palpation. Blood investigations were normal including hormonal examination. She has benefited an abdominal ultrasound scan that demonstrated a heterogeneously hypoechoic lesion measuring $20 \times 20 \times 17 \mathrm{~cm}$ in upper pole of the left kidney.

An adrenal protocol CT scan was performed revealing a $20 \mathrm{~cm} \times 20 \mathrm{~cm}$ left suprarenal cystic lesion enhanced after injection of contrast agent with a calcified rim (Figure 1(a) \& Figure 1(b)). A renal or adrenal origin of the mass was

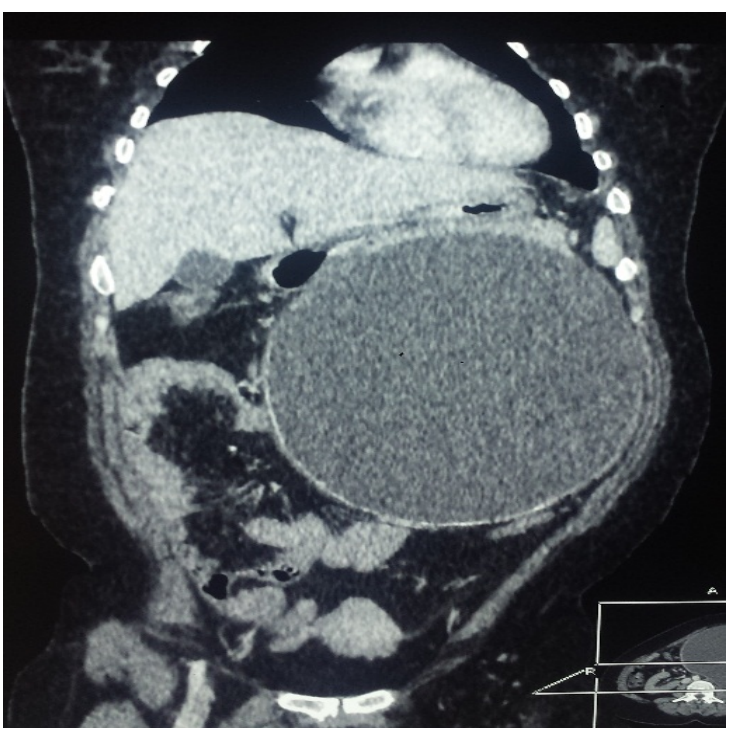

(a)

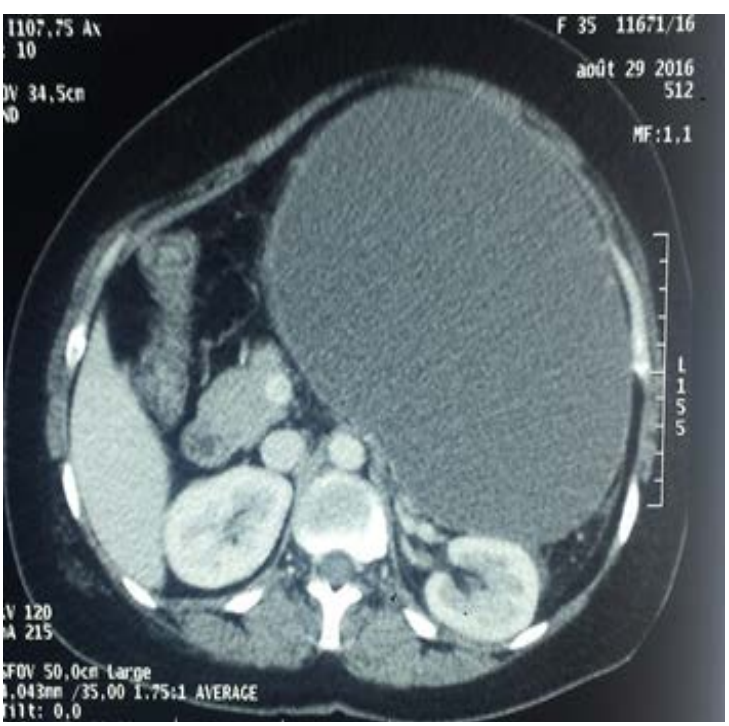

(b)

Figure 1. An enhanced computed tomography of the abdomen revealed a giant homogeneous low density mass lesion in the left adrenal region. 
difficult to distinguish.

MRI revealed a $20 \times 20 \mathrm{~cm}$ well-defined mass, which appeared low intensity in the $\mathrm{T}$ 1-weighted image (Figure 2(a)) and high intensity in the T 2-weighted image (Figure 2(b)), arising from the left adrenal gland. The left kidney was displaced downward by the mass. The adrenal gland and the mass were then mobilized, excised en-bloc and sent for histology for histological evaluation.

At macroscopic examination, the specimen has corresponded a unilocular cystic mass, measuring $20 \times 19 \mathrm{~cm}$, with a fibrous capsule containing a redbrownish material (Figure 3 ).

The histological examination showed that the cystic wall was $1.3 \mathrm{~cm}$ thick and consisted of dense compact fibrous tissue, without an epithelial or endothelial lining. There were areas of dystrophic calcifications within the fibrous tissue. Then cyst appeared to arise in continuity with the adrenal cortex and medullary tissues, and a diagnosis of an adrenal pseudocyst was made (Figure 4). Postoperative follow-up (10 days after the operation) were uneventful and hypochondralgia

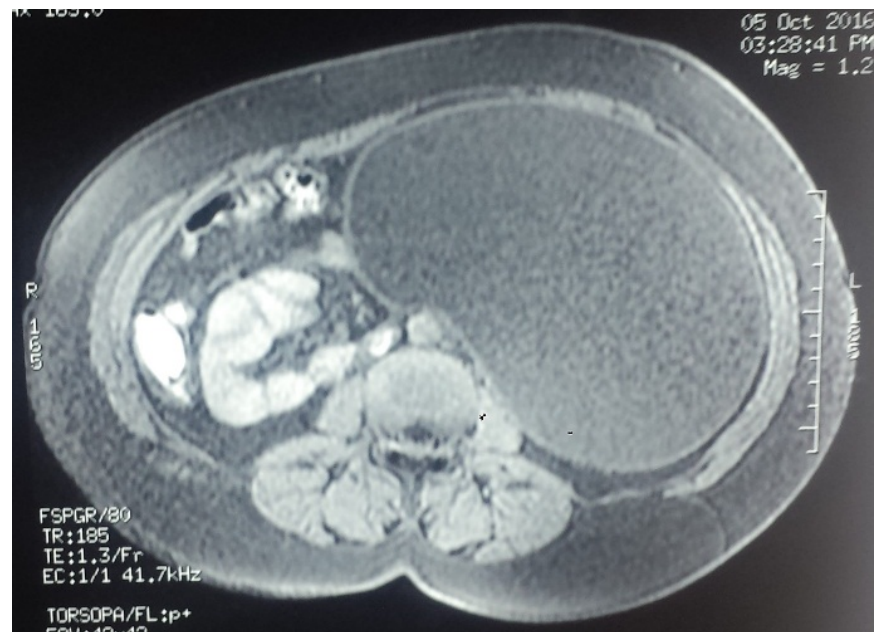

(a)

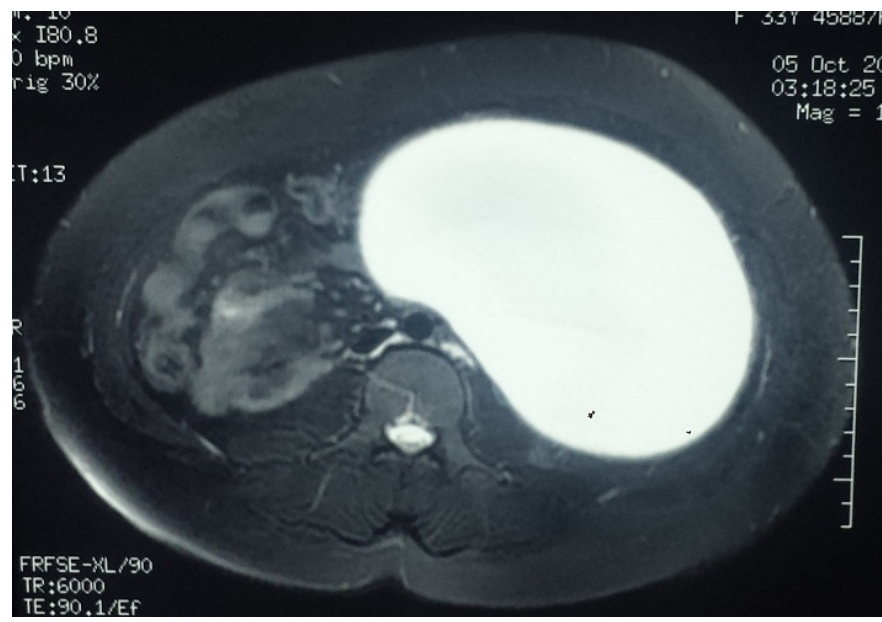

(b)

Figure 2. Abdominal magnetic resonance imaging revealed a well-defined low intensity mass in the $\mathrm{T} 1$-weighted image (a) and hight intensity in the T 2 -weighted image (b). 


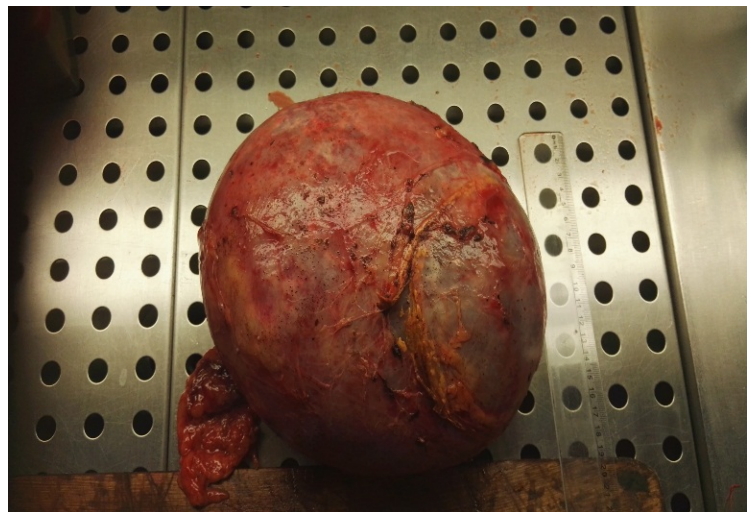

Figure 3. The gross adrenal specimen; the cystic structure measuring $19 \mathrm{~cm} \times 19 \mathrm{~cm}$.

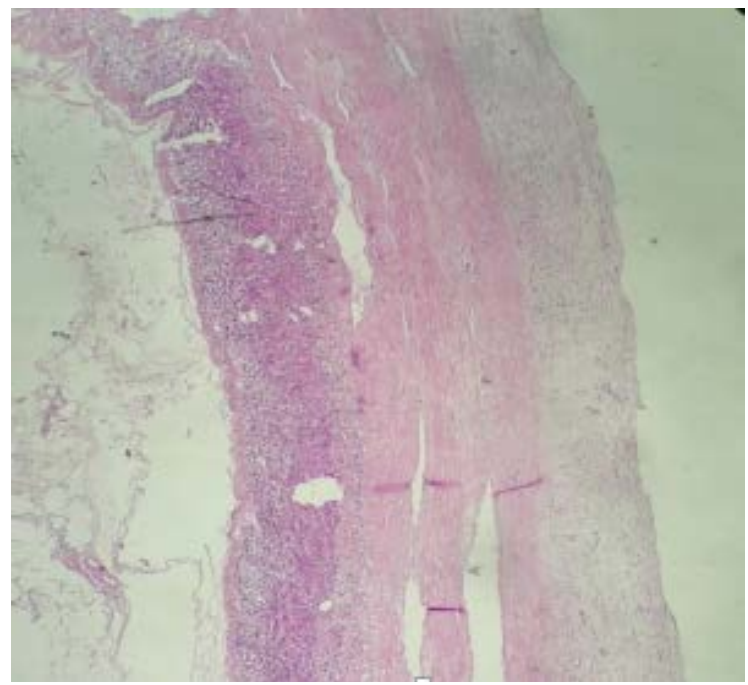

(a)

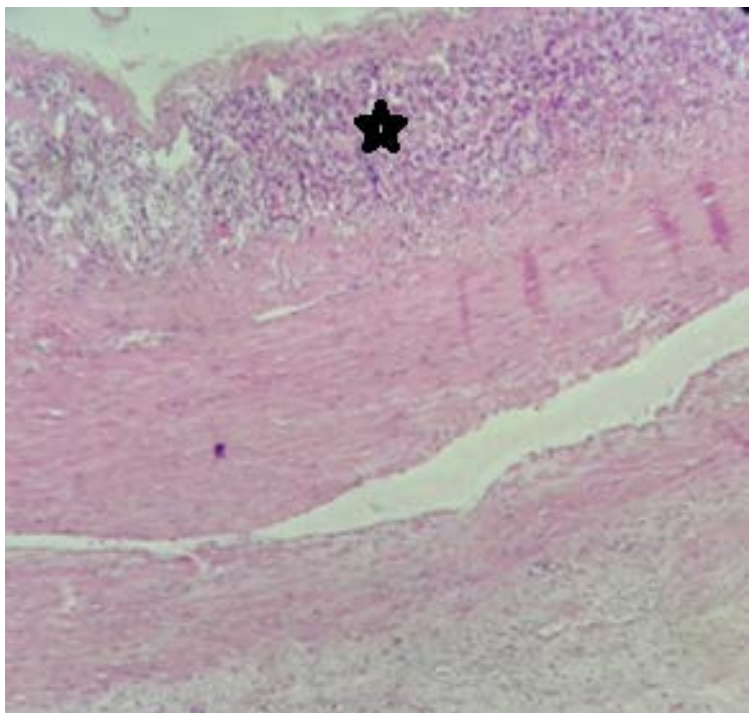

(b)

Figure 4. Histological examination of the cyst showed an adrenal pseudocyst. The cystic wall consisted of dense fibrous tissue without an epithelial lining. A rim of normal adrenal tissue was found compressed within the cystic capsule (star). (Hematoxylin and eosin stain. (a) $(\times 10)$; (b) $(\times 20)$. 
and abdominal distention are disappeared after pseudocyst removal.

\section{Discussion}

Historically, in 1670 Viennese anatomist Greiselius first described an adrenal cyst. In 1903, Doran attributed the first case of adrenal cyst to Greiselius [2]. Adrenal cysts are relatively rare lesions and most of them are nonfunctioning and asymptomatic [3] [4].

The classification of adrenal cysts initially described by Abeshouse, and modified in 1966 by Foster, is divided into four groups by histologic type: endothelial cysts, pseudocysts, epithelial cysts, and parasitic cysts [5].

Epidemiologically, adrenal cysts are more common in women and typically are found between the ages of 30 and 60 [6]. In some series, a female preponderance of about $3 / 1$ has been noted for unknown reasons [7].

Adrenal pseudocysts are rare, but constitute approximately $32 \%-80 \%$ of all adrenal cysts. The malignant potential of adrenal pseudocysts is $7 \%$ and the risk increases with the size of the pseudocyst [8].

Generally, adrenal cysts are asymptomatic but larger cysts can give rise to lumbar pain, vomiting, gastrointestinal discomfort or an abdominal mass [9]. Some may also present as an acute abdomen, usually due to intracystic haemorrhage, rupture, or infection [10].

The above newly developed imaging techniques can detect and localize these lesions with high accuracy, but it remains difficult to differentiate malignancy, cortical adenoma, hyperplasia, or pheochromocytoma from benign cysts [11]. The gold standard for studying adrenal masses is CT, which can detect small tumors with a sensitivity of $100 \%$ [12]. MRI can obtain more information on the anatomical details and nature of complicated intracystic components [13].

Macroscopically pseudocysts are usually large uniloculated cysts, with walls composed of dense, fibrous connective tissue. The walls are usually $1-$ to $5-\mathrm{mm}$ thick, but may be up to $3 \mathrm{~cm}$ in rare cases and a red-brown content consisting of fibrin and necrotic debris [14] [15].

Microscopically; adrenal pseudocysts are cystic lesions that consist of a thick fibrous tissue wall devoid of epithelial or endothelial lining and arising as a result of hemorrhage within a normal or pathologic adrenal gland [16].

No consensus exists for surgical management, some authors privileged surgery for all adrenal cysts, and others a more conservative. However some authors recommended surgical management for symptomatic and functional cysts, a large cyst (more than $5 \mathrm{~cm}$ ) and heterogeneous cyst [17]. The evolution is generally good [18], as was the case for our patient.

\section{Conclusion}

An adrenal pseudocyst is a rare lesion. Symptoms are usually related to the size and local pressure effect of the cysts. Imaging confirms the cystic nature of the mass. Only the study Pathology provides diagnostic certainty and excludes malignant lesions. Surgery is the treatment of choice. 


\section{References}

[1] Carvounis, E. (2006) Vascular Adrenal Cysts a Brief Review of the Literature. Archives of Pathology \& Laboratory Medicine, 130, 1722-1724.

[2] Doran, A.H.G. (1908) Cystic Tumor of the Supra-Renal Body Successfully Removed by Operation. BMJ, 1, 1558-1563. https://doi.org/10.1136/bmj.1.2478.1558

[3] Karayiannakis, A.J., Polychronidis, A. and Simopoulos, C. (2002) Giant Adrenal Pseudocyst Presenting with Gastric Outlet Obstruction and Hypertension. Urology, 59, 946viii-946ix.

[4] Cavallaro, A., De Toma, G., Mingazzini, P.L., et al. (2001) Cysts of the Adrenal Gland: Revision of a 15-Year Experience. Anticancer Research, 21, 1401-1406.

[5] Foster, D.G. (1966) Adrenal Cysts. Review of Literature and Report of Case. Archives of Surgery, 92, 131-143.

https://doi.org/10.1001/archsurg.1966.01320190133032

[6] Wieneke, J.A. and Thompson, L.D.R. (2006) Non-Neoplastic Lesions of the Adrenal Gland. In: Thompson, L.D.R., Ed., Endocrine Pathology, Foundations in Diagnostic Pathology, Vol. 5, Churchill Livingstone Elsevier, Philadelphia, 183-204.

[7] Abeshouse, G.A., Goldstein, R.B. and Abeshouse, B.S. (1959) Adrenal Cysts: Review of the Literature and Report of Three Cases. Journal of Urology, 81, 711-719.

[8] Kar, M., Pucci, E. and Brody, F. (2006) Laparoscopic Resection of an Adrenal Pseudocyst. Journal of Laparoendoscopic \& Advanced Surgical Techniques, 16, 478481. https://doi.org/10.1089/lap.2006.16.478

[9] Mohan, H., Aggarwal, R., Tahlan, A., Bawa, A.S. and Ahluwalia, M. (2003) Giant Adrenal Psuedocyst Mimicking a Malignant Lesion. Canadian Medical Association Journal, 46, 6 .

[10] Sroujreh, A.S., Farah, G.R., Haddad, M.J. and Abu-Khalaf, M.M. (1990) Adrenal Cyst; Diagnosis and Treatment. British Journal of Urology, 65, 570-575. https://doi.org/10.1111/j.1464-410X.1990.tb14822.x

[11] Chew, S.P., Sin, R., Teoh, T.A. and Low, C.H. (1999) Hemorrhage into Nonfunctioning Adrenal Cysts; Report of Two Cases and Review of the Literature. Annals Academy of Medicine Singapore, 28, 863-866.

[12] Yip, L., Tublin, M.E. and Falcone, J.A. (2010) The Adrenal Mass: Correlation of Histopathology with Imaging. Annals of Surgical Oncology, 17, 846-852. https://doi.org/10.1245/s10434-009-0829-2

[13] Elsayes, K.M., Mukundan, G. and Narra, V.R. (2004) MR Imaging Features with Pathologic Correlation. Radiographics, 24, S73-S86. https://doi.org/10.1148/rg.24si045514

[14] Castillo, O.A., Litvak, J.P., Kerkebe, M., et al. (2005) Laparoscopic Management of Symptomatic and Large Adrenal Cysts. Journal of Urology, 173, 915-917. https://doi.org/10.1097/01.ju.0000152177.35204.70

[15] Medeiros, L.J., Lewandrowski, K.B. and Vickery, A.L. (1989) Adrenal Pseudocyst: A Clinical and Pathologic Study of Eight Cases. Human Pathology, 20, 660-665.

[16] Neri, L.M. and Nance, F.C. (1999) Management of Adrenal Cysts. The American Surgeon, 65, 151-163.

[17] Bellantone, R., Ferrante, A., Raffaelli, M., et al. (1998) Adrenal Cystic Lesions: Report of 12 Surgically Treated Cases and Review of the Literature. Journal of Endocrinological Investigation, 21, 109-114. https://doi.org/10.1007/BF03350324

[18] Rakoto-Ratsimba, H.N.A.F., Rakototiana, A.F.H.D., Andrianiaina, H.D., Rahaingo, M.M.A. and Ranaivozanany, A. (2007) Large Adrenal Pseudocyst. A Case Report. Revue Tropicale de Chirurgie, 1, 1-2. 
Submit or recommend next manuscript to SCIRP and we will provide best service for you:

Accepting pre-submission inquiries through Email, Facebook, LinkedIn, Twitter, etc. A wide selection of journals (inclusive of 9 subjects, more than 200 journals)

Providing 24-hour high-quality service

User-friendly online submission system

Fair and swift peer-review system

Efficient typesetting and proofreading procedure

Display of the result of downloads and visits, as well as the number of cited articles Maximum dissemination of your research work

Submit your manuscript at: http://papersubmission.scirp.org/

Or contact ss@scirp.org 